\title{
Predictors of Household Food Sufficiency in Singida Municipality, Tanzania
}

\author{
Emmanuel Simon Mwang'onda ${ }^{1, *}$, Peter Elia Mosha ${ }^{2}$, Steven Lee Mwaseba ${ }^{1}$ \\ ${ }^{1}$ Regional Department, Institute of Rural Development Planning (IRDP), Dodoma, Tanzania \\ ${ }^{2}$ Department of Population Studies, Institute of Rural Development Planning (IRDP), Dodoma, Tanzania
}

Email address:

esimon@irdp\#c.tz (E. S. Mwang'onda)

${ }^{*}$ Corresponding author

\section{To cite this article:}

Emmanuel Simon Mwang'onda, Peter Elia Mosha, Steven Lee Mwaseba. Predictors of Household Food Sufficiency in Singida Municipality, Tanzania. Social Sciences. Vol. 8, No. 3, 2019, pp. 132-140. doi: 10.11648/j.ss.20190803.19

Received: May 3, 2019; Accepted: June 3, 2019; Published: July 9, 2019

\begin{abstract}
Incidences of food shortage and poverty are highly reported on Africa specifically sub-Saharan part, despite having a large number of the population engaging in agriculture residing in the rural area. Different scholars have managed to associate food security which involves food availability, food access, food utilization and stability at the household level with various factors. The study takes a similar root in pinning down factors related to the food shortage in Singida. Taking into account socio-economic characteristics of household in analysis, it is indicated that food shortage in Singida area is more pronounced during farming season, that is November to March and it is associated with gender, marital status, education level, occupation and place of residence of the household head. Meanwhile, age of head of household, total manpower in the household, amount of maize harvested, the use of fertilizer, farm size and household expenditure on food had no significant effect in determining food shortage at the household level. Since education has shown a significant positive effect of not having food shortage, and community in Singida depends much on rain-fed agriculture system, the problem of food shortage may be tackled through extension services toward creating awareness on improved agriculture practice for more farm yield given the small piece of land available, and improvement in storage mechanism.
\end{abstract}

Keywords: Food Shortage, Poverty, Hunger, Small Scale Agriculture

\section{Background}

Food shortage exists in a given region if, food supplies fall short of existing food demand for provision of energy and nutrients to a given population, and this may occur unevenly within a given region, while a certain proportion of population in a region may be experiencing hunger from limited access to adequate food, others may be enjoying access to plenty of food existing [1]. Incidences of food shortage and poverty are frequently reported sub-Saharan Africa, despite having the large number of population engaging in agriculture residing in a rural area [2-3]. The Maputo declaration in 2003, vividly shows that everyone agrees that if the agricultural sector is well managed, attainment of food security, poverty reduction and overall wellbeing of the nation will be highly possible [4]. The state and nutrition security of food in the world report produced by
FAO in 2017 shows that, undernourished population globally has increased to 815 million compared to 777 million that was reported in 2015, with high prevalence rate in Eastern Africa with a rate of 34 per cent compared to 20 per cent of the other Africa's regions [5].

Shortage of food has been associated with various factors which are reported at local, national and regional levels. However, the current global decline in food availability has been related to; existing conflicts within various countries for example of the case of South Sudan, Syria, Libya and Yemen. Other factors include; weather variations whereby El Niño and drought having been reported in some regions, limited fiscal space and the declining power of domestic currency that erode the capacity of a country to import food to sustain the life of its population [5].

Nevertheless, different scholars have managed to associate food security which involves food availability, food access, 
food utilization and stability at household level with various factors including; age and gender, household assets, poor storage, market access and distance to main road, marital status and education of head of household, farm size, offfarm activities, and weather variability and climate change [6-13].

Tanzania, as other developing countries have a large percentage of its population engaging in small scale agriculture, whereby more than 50 per cent of its population cultivate on farm size not more than five hectares while relying on family labour force $[3,15,16]$. However, despite having more than 80 per cent of its population employed in agriculture growing mostly maize, beans, paddy, and millet for food purposes, still, the country repeatedly reports food shortage from different regions. The highly affected area is Central part of the country, which includes the regions like Dodoma, Singida, Tabora and Shinyanga, these regions are characterised with semi-arid kind of climate [14, 17].

At the national level, based on National Panel survey report released in 2017, more than 34 per cent of households were reported to be worrying about not having enough food or experiencing negative changes in their diet, this is as per a survey conducted in 2014/15 [16]. While a survey conducted by Twaweza, indicates more than 78 per cent of households experienced food shortage in their locations and out of ten households, seven reported being worried about experiencing food shortage [18].

Various studies conducted at a household level significantly relate food security matters in Tanzania with; unplanned settlement, farming versus harvesting seasons, food prices, household size, farm size and total harvest, farmers market linkage and rural-urban migration [19-26]. In order to intensify the fight against poverty and hunger in Africa and other regions of the world, research studies are greatly demanded to collaborate with other sets of strategies that are already in place.

Repeatedly, semi-arid regions in Tanzania have been reported to experience insufficiency of food $[14,16]$. Several strategies have been set on place in tackling the problem including increasing access to extension services, promotion of drought-resistant crops such as millet, sorghum and cassava and establishment of grain reserve agency to ensure sufficient availability of food at affordable prices [27]. With these efforts and long experience of having a shortage, the society living in semi-arid regions are expected to have learned and adopted ways to enhance the availability of food in their households. However, the problem continues to prevail, leading to the intent of having this study.

\section{Materials and Methods}

\subsection{Location, Area Coverage and Population}

Data for this paper were collected in Singida Municipality which is located in the central plateau of Tanzania between latitudes $40^{\circ} 40^{\prime}$ and $40^{\circ} 53^{\prime}$ South of the Equator and longitude $340^{\circ} 30^{`}$ and $340^{\circ} 53^{`}$ East of Greenwich. Singida
Municipality covers a total land area of 754 square kilometres, whereby arable land covers 244.9 square kilometres, forest area covers 7.8 square kilometres, and grazing area covers 246.1 square kilometres. Administratively, Singida municipality is divided into 18 wards, which are further subdivided into 49 Mitaa and 20 Villages.

Based on the 2016 household population data, the municipality had a total of 37,159 households, with an average household size of 5.82 . The population was 168,428 in 2012 compared to the 2002 census which was 61,156 people. The population grew by 107,272 people between 2002 and 2016. Given the population growth rate, it is projected that the number will be 255,286 people in the year 2020 .

\subsection{Climate Condition}

The average temperature in the study area for years 2006 to 2015 ranged between $24^{\circ} \mathrm{C}$ to $31^{\circ} \mathrm{C}$. Months with the highest temperature in the year are November and December, while coldest months are June, July and August with temperature ranging $11.7^{\circ} \mathrm{C}$ to $12.9^{\circ} \mathrm{C}$. Moreover, the average rainfall for years 2006 to 2015 ranges from $215.5 \mathrm{~mm}$ to $493.6 \mathrm{~mm}$. The year 2008 was the one which recorded the highest amount of rainfall while the year 2012 recorded the least amount of rainfall in the given period. Also, the average number of rain days for the same period ranges from 21 days in 2014 to 43 days in the year 2006. The area is dominated by a dry season from June to October. Rainfall is very unreliable and the soil is reddish-brown loamy sand, grey clays soil in this area is under depressions.

\subsection{Data Collection and Processing}

This paper uses data collected 2016 of Singida Municipality social economic profile. With a well-trained team of enumerators, 6404 household heads were interviewed using a semi-structured questionnaire. Data collectors were stationed in all 18 wards under supervision during data collection. IBM SPSS version 20 was used to capture, clean, manipulate and analyse the collected data.

\subsection{Data Analysis and Regression Model Estimation}

In order to establish food sufficiency or shortage status in Singida, both descriptive and inferential statistical techniques were employed to study the data. Descriptively, frequencies, mean and multiple response analysis of some of the variables was run to characterise studied households. Student t-test was used to compare means of quantitative data to establish if there are any similarities of means for households with food shortage and those who are food sufficient.

Multiple binary logistic regression was then used to establish the relationship of various predictors for food sufficient. In this paper it was intended to establish if there is relationship between household reporting food sufficiency (Dependent variable) and various socio-demographic, social economic variables such as household head sex, age (in 
years), marital status, number of years spent in schooling, household size, farming as a major economic activities (when compared to other activities), residency status (if one live in urban or rural settings), livestock keeping (as compared to households not keeping households), number of cattle kept, amount of maize harvested in the last year, number of chicken, amount of sorghum harvested in last year, farm size owned, participating in an off-farm activity, household annual estimated cost for food (in 00,000 Tshs) and household annual income (00,000 Tshs). During analysis, the first category for each independent variable was used as a reference category. Statistical significance was set at $\mathrm{p}<0.05$. The model for this analysis is as indicated below:

$$
\ln \left(\frac{P\left(Y_{i}=1\right)}{1-P\left(Y_{i}=1\right)}\right)=\alpha+\beta_{1} x_{1 i}+\beta_{2} x_{2 i}+\cdots+\beta_{16} x_{16 i}
$$

Where by;

$P\left(Y_{i}=1\right)$ Probability that a household is food sufficient

$x_{1}=$ Sex of the head of household $(1=$ male, $0=$ female $)$

$x_{2}=$ Residency status $(1=$ lives in urban settings, $0=$ lives in a rural area

$x_{3}=$ Age of the head of household in years (continuous)

$x_{4}=$ Head of the household marital status $(1=$ Married, $O=$ Otherwise

$x_{5}=$ Number of years spent in schooling by the head of the household (continous)

$x_{6}=$ Household size (continuous variable)

$x_{7}=$ Households with farming as major economic activity $(1=Y e s, 0=N o)$

$x_{8}=$ Households with li estock as a major economic activity $(1=Y e s, 0=N o)$

$x_{9}=$ Number of cattle kept (continuous variable)

$x_{10}=$ Number of chicken kept by the household (continuous variable)

$x_{11}=$ Amount of maize harvested in last season 2015 (kilos)

$x_{12}=$ Amount of Sorghum harvested 2015 (kilos)

$x_{13}=$ Total farm size owned by the household (acres)

$x_{14}=$ Household participating in an off - farm activity $(1=Y e s, 0=N o)$

$x_{15}=$ Annual household average cost for buying food $(00,000$ Tshs $)$

$x_{16}=$ Annual Household average income (00,000Tshs)

$\alpha=$ Regression constan

\section{Results}

Quantitative and qualitative data were collected in 2016 from 6404 households. The information gathered include demographic characteristics of the households, status of food availability at the household level and factors influencing household food shortage in these areas.

\subsection{Socio-Demographic Household Characteristics}

Household demographic and socioeconomic characteristics are known to affect food shortage in many developing countries as discussed on part of the introduction. Table 1 presents results on household demographic and socioeconomic characteristics.

Table 1. Household Socio-demographic Characteristics.

\begin{tabular}{|c|c|c|}
\hline Variable & Number of Observations & Per cent \\
\hline \multicolumn{3}{|l|}{ Sex of head of Household } \\
\hline Male & 4507 & 70.4 \\
\hline Female & 1897 & 29.6 \\
\hline \multicolumn{3}{|l|}{ Marital Status } \\
\hline Singles & 457 & 7.1 \\
\hline Married & 4318 & 67.4 \\
\hline Living together & 509 & 7.9 \\
\hline Divorced & 176 & 2.7 \\
\hline Widow/widower & 734 & 11.5 \\
\hline \multicolumn{3}{|l|}{ Education Level } \\
\hline No Formal Education & 726 & 11.3 \\
\hline Primary school Education & 4122 & 64.4 \\
\hline Secondary School Education & 982 & 15.3 \\
\hline College / University Education & 533 & 8.3 \\
\hline \multicolumn{3}{|c|}{ Major Household Economic Activity* } \\
\hline Farming & 3801 & 60.0 \\
\hline Livestock Keeping & 3165 & 49.9 \\
\hline Business & 2332 & 36.8 \\
\hline Government Employee & 705 & 11.1 \\
\hline
\end{tabular}




\begin{tabular}{|c|c|c|}
\hline Variable & Number of Observations & Per cent \\
\hline \multicolumn{3}{|l|}{ Sex of head of Household } \\
\hline Private Sector Employee & 481 & 7.6 \\
\hline Carpenter & 61 & 1.0 \\
\hline Food Vending & 37 & 0.6 \\
\hline Ownership & & \\
\hline Owned by Household head & 4752 & 75.0 \\
\hline Rented & 1201 & 18.9 \\
\hline Living employers House & 133 & 2.1 \\
\hline Living Relatives House & 254 & 4.0 \\
\hline
\end{tabular}

*multiple responses

Head of the household was a sample unit in the study because are responsible for making major decisions at a family level including ensuring that their household has enough food. The study shows gender wise, households are divided as 70 per cent male-headed households and 30 per cent female-headed households. In Tanzania, most of societies follow patrilineal hierarch system, whereby a man is head of the family and has the responsibility of taking major family decisions while carrying out major responsibility including providing food and shelter to family members. In a few cases, females also lead the household due to death of the husband. It was also found that most households were headed by married individuals, 67 per cent followed by widow/widowers which accounted for 12 per cent. Other demographic and socioeconomic variables include; education level of household heads, whereby major of them (64 per cent) had primary school education with only 8 per cent attaining tertiary level education. Major economic activity for most households' heads was farming 60 per cent, followed by livestock keeping 50 per cent, those who are employed either in public sector or private sector were not more than 20 per cent.

Table 2. Household Characteristics.

\begin{tabular}{|c|c|c|c|c|c|}
\hline Variable & $\mathbf{N}$ & Min & Max & Mean & SD \\
\hline Age of the household head in years & 6397 & 18 & 98 & 46.5 & 14.3 \\
\hline Number of years spent by the head of the household in schooling & 6404 & 0 & 27 & 7.4 & 4.0 \\
\hline Total number of household members & 6370 & 1 & 19 & 5.8 & 2.9 \\
\hline Number of household members aged between 15 and 64 years & 6237 & 1 & 22 & 3.5 & 2.1 \\
\hline Number of household members aged above 64 years of age & 6404 & 0 & 10 & 0.3 & 0.8 \\
\hline Number of household members less than 4 years of age & 6404 & 0 & 12 & 0.6 & 0.9 \\
\hline Number of household members aged between 4 and 14 years & 6404 & 0 & 34 & 1.5 & 1.6 \\
\hline
\end{tabular}

The results also showed that on average; the household size was 5.8 people, household head age was 46.5 years while the household size for people who are able to work (15 to 64 years) was 3.5 people. The data revealed most households having enough manpower for farming activities. The mean value for children and elderly was 0.8 people.

\subsection{Food Shortage Status in Singida Municipality}

Household heads were asked if they have ever experienced food shortage for the past five farming and harvesting seasons in identifying food shortage experience among Singida Municipality dwellers. The data revealed that out of 6404 households, 3702 households which is equivalent to 57 per cent reported having experienced food shortage in previous five years (2011-2015), whereby by mostly reported year of the shortage was 2015 with 75 per cent reported cases compared to other years.

\subsubsection{Household Experience on Food Shortage}

Food shortage varies from year to year in this study area. The data was collected on which year was reported by many households experiencing food shortage. Table 3 shows 2015 was the year reported by many households $(75 \%$ of all interviewed heads of households) to have a food shortage, followed by 2014. 2016 showed the least food shortage percentage-wise as the data was collected in June. From households' food shortage experience, respondents were asked to indicate in which time of the year (month) that most families face food shortage.

Table 3. Household years of experiencing food shortage (multiple responses).

\begin{tabular}{llll}
\hline \multirow{2}{*}{ Years } & \multicolumn{2}{l}{ Responses } & Per cent of Cases \\
\cline { 2 - 3 } & $\mathbf{N}$ & Per cent & $24.8 \%$ \\
2011 & 898 & $11.0 \%$ & $29.7 \%$ \\
2012 & 1075 & $13.1 \%$ & $40.6 \%$ \\
2013 & 1472 & $18.0 \%$ & $55.4 \%$ \\
2014 & 2010 & $24.5 \%$ & $75.5 \%$ \\
2015 & 2738 & $33.4 \%$ & $0.1 \%$ \\
2016 & 5 & $0.1 \%$ & $226.2 \%$ \\
Total & 8198 & $100.0 \%$ & \\
\hline
\end{tabular}




\subsubsection{Food Shortage Cycle}

Figure 1 below, indicates the number of cases per months when household encountered food shortage.

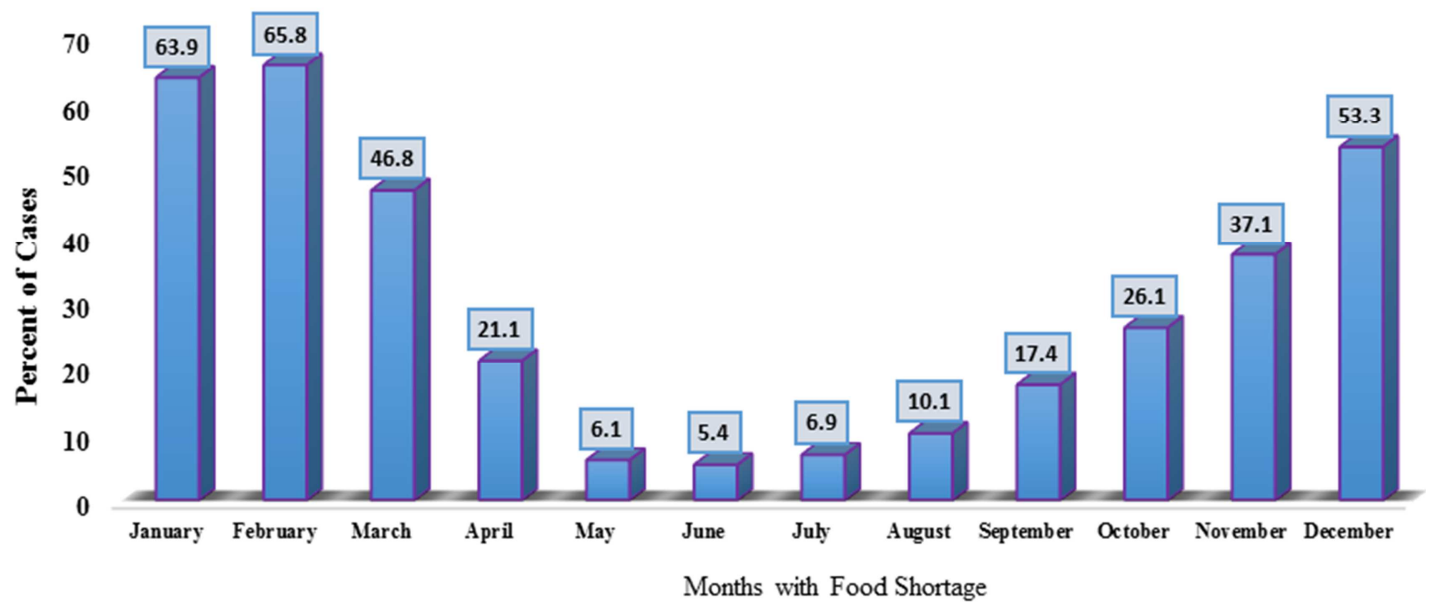

Figure 1. Months with Food shortage.

From the figure, it can be observed that months with many cases of food shortage were December, January and February, of which many households (66 per cent) reported to experience food shortage in February compared to other months of the year. The period between May and August, less number of households experienced food shortage, the lowest per cent being 5 per cent in June. Moreover, a rapid decline in the number of households reported to have experienced a food shortage between March and May is observed.

Shortage of food as per households' opinions has been associated with; the poor harvest of food crops, destruction of crops by pest and diseases, destruction of stored harvests, weather condition and selling of food crops in demand of cash as indicated on table 4 below.

Table 4. Reasons for food shortage.

\begin{tabular}{lll}
\hline Reasons & Frequency & Per cent \\
\hline Poor harvest of food crops & 1827 & 50.5 \\
Crops were destroyed in the farm by pest and diseases & 866 & 23.9 \\
Crops were destroyed where they were stored & 307 & 8.5 \\
\hline
\end{tabular}

\begin{tabular}{lll}
\hline Reasons & Frequency & Per cent \\
\hline Poor weather condition for a better harvest & 2677 & 74.0 \\
Sell of food crops for the demand for cash & 332 & 9.2 \\
\hline
\end{tabular}

Most of the households commented that they are experiencing food shortage because of poor weather condition which is largely resulting from poor harvest of food crops whereby on average, households in Singida cultivate an average of 2.8 hectors of land for subsistence.

\subsection{Factors Influencing the Status of Household Food Shortage in Singida}

During analysis, factors influencing the status of food shortage were considered into two categories; quantitative and qualitative factors.

\subsubsection{Household Food Shortage in Relation to Demographic Factors}

Student t-test statistic was used to test the association between food shortage against quantitative household characteristics as presented in Table 5 below:

Table 5. Summary of Means of continuous variables for Food shortage status.

\begin{tabular}{|c|c|c|c|c|c|}
\hline \multirow{2}{*}{ Variable } & \multicolumn{2}{|c|}{ Household with Food Shortage } & \multicolumn{2}{|c|}{ Households with no Food shortage } & \multirow{2}{*}{ t-value } \\
\hline & Mean & SD & Mean & SD & \\
\hline Age of Household Head (years) & 48.5 & 14.3 & 44.0 & 13.8 & $12.4^{*}$ \\
\hline Number of Years Spent by Head of the Household in Schooling & 6.2 & 3.2 & 8.9 & 4.3 & $-29.2 *$ \\
\hline Total Number of Household members & 6.4 & 2.9 & 5.1 & 2.6 & $18.3^{*}$ \\
\hline Total Number of Cattles kept by the Household & 8.9 & 10.2 & 15.0 & 105.6 & $-2.3 \mathrm{NS}$ \\
\hline Amount of Maize Harvested for the year 2014/2016 in kilograms & 1105.3 & 17734.4 & 1756.4 & 14083.5 & $-0.9 \mathrm{NS}$ \\
\hline Estimated Household Annual Income in Tanzanian shillings & 2484118.4 & 10291800.6 & 6953438.8 & 28258195.0 & $-8.6^{*}$ \\
\hline Total Household cost for Buying Food & 973565.8 & 1812635.9 & 1900517.1 & 2887043.9 & $-14.6^{*}$ \\
\hline Total Household Savings & 858799.0 & 1012470.6 & 1411828.1 & 5144183.3 & $-7.8^{*}$ \\
\hline
\end{tabular}

NS and * means not significant and Significant at $5 \%$ probability levels respectively

It can be seen from Table 5 above that there is a statistical difference in age, a number of years spent in schools, household size, size of land owned, household income, amount of cash spent in buying food and amount of savings 
between households with food shortage and those who did not have food shortage.

\subsubsection{Food Shortage in Relation to Household Economic Status}

The analysis also focused on assessing the relationship between food shortage and categorical household characteristics. It was observed that categorical variables such as sex of the head of household and marital status of the head of the household do not have an association with whether the household experiences food shortage or not. But it was revealed in the other hand that there is a significant association between the education level of the head of household, use of fertilizers and residential house ownership with household experiencing food shortage or not (See Table 6).

Table 6. Association between household food shortage and household characteristics.

\begin{tabular}{|c|c|c|c|c|c|c|c|c|}
\hline \multirow{2}{*}{ Variable } & & \multicolumn{2}{|c|}{ Food Shortage } & \multicolumn{2}{|c|}{ No Food Shortage } & \multicolumn{2}{|l|}{ Total } & \multirow[t]{2}{*}{ Chi-Square } \\
\hline & & No & $\%$ & No & $\%$ & No & $\%$ & \\
\hline \multirow{2}{*}{ Sex of head of household } & Male & 2549 & 70.4 & 1889 & 70.2 & 4447 & 70.3 & \multirow{2}{*}{$0.013^{\mathrm{NS}}$} \\
\hline & Female & 1073 & 29.6 & 804 & 29.8 & 1877 & 29.7 & \\
\hline \multirow{2}{*}{ Head of household education level } & No formal education & 527 & 14.5 & 191 & 7.1 & 718 & 11.4 & \multirow{2}{*}{$86.056^{*}$} \\
\hline & With formal education & 3095 & 85.5 & 2511 & 92.9 & 5606 & 88.6 & \\
\hline \multirow{2}{*}{ Marital status } & Not married & 1154 & 31.9 & 910 & 33.7 & 2064 & 32.6 & \multirow{2}{*}{$2.326^{\mathrm{NS}}$} \\
\hline & Married & 2468 & 68.1 & 1792 & 66.3 & 6324 & 67.4 & \\
\hline House ownership & Owns a house & 2998 & 82.8 & 1703 & 63.0 & 4701 & 74.3 & $2.326^{*}$ \\
\hline \multirow{2}{*}{ Use fertilizer } & Uses & 2179 & 72.0 & 795 & 63.5 & 2974 & 69.6 & \multirow{2}{*}{$30.079 *$} \\
\hline & Do not use & 846 & 28.0 & 456 & 36.5 & 1302 & 30.4 & \\
\hline
\end{tabular}

NS $=$ Not significance, $*$ Significance at $5 \%$ probability levels.

\subsubsection{Logistic Regression for Factors Influencing Food Shortage at Household Level}

Results presented in Table 7 summarizes the results of the model. It was reported that various factors are responsible for food shortage at household level in Singida municipality including; residence area, sex of the head of household, marital status, years spent in schooling, household size, farming as a major economic activity, livestock keeping as a major economic activity, number of cattle kept, number of chicken, amount of money spent in buying food, amount of household savings and also household annual income. These variables are detailed explained below.

Table 7. Logistic Regression for Factors influencing Food Shortage at Household Level.

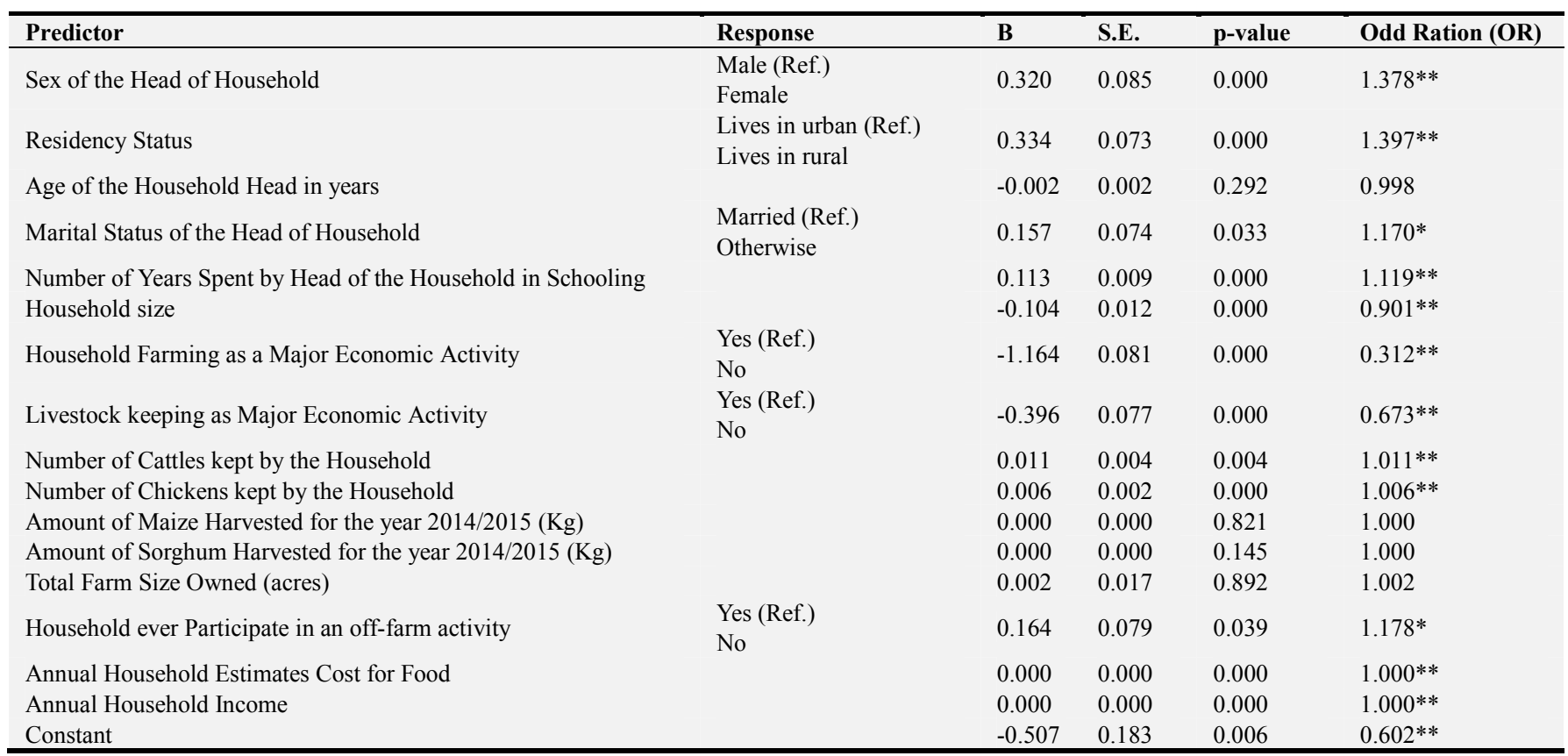

S.E. $=$ Standard Error, Ref. $=$ Reference category; $*=$ Significant at $\mathrm{p}<0.05 ; * *=$ Significant at $\mathrm{p}<0.01$ Nagelkerke $\mathrm{R}^{2}=0.343$, Cox $\&$ Snell $\mathrm{R}^{2}=0.250$

The multiple binary logistic model results, using the omnibus test model coefficients revealed that inclusion of variables into the model contributed significantly to model fit with $\chi^{2}=1884.5, d f=16$ and $p<0.0001$, this implying each addition of variables into the model had significant improvement to the better fit of the model. Also, the results through Cox \& Snell and Nagelkerke R-squares showed that 25.5 per cent and 34.3 per cent of all variations observed in 
food shortage can be explained by the model explanatory variables respectively as presented on Table 7 above; with correct overall classification rate increasing from 57.8 per cent to 74.5 per cent after entering all variables.

The model results indicated that sex of the head of the household, residency area, household head marital status, years spent in schooling, household size, farming as a major economic activity, livestock keeping, number of cattle kept by household, number of chicken kept, if household had any off-farm activity, annual household cost for food and annual household income had significant influence on the probability of influencing household food sufficiency status. On the other hand; the age of the head of household, amount of maize harvested, amount or sorghum harvested (season 2014/2015) and total farm size owned, did not significantly predict household food sufficiency in the study area.

The results more specifically indicate households headed by males were more likely to reporting food sufficiency by 38 per cent when compared to households headed by a female $(\mathrm{OR}=1.38)$. Living in urban areas was also more likely to be food sufficient as compared to rural households. Increasing age of the head of household by one unit was associated with increased odds for reporting food insufficiency. $(\mathrm{OR}=0.998, \mathrm{p}>0.05)$ although the results were not statistically significant. Married heads of households when compared to those who were not married were 17 per cent more likely to reporting food sufficiency $(\mathrm{OR}=1.17)$ while increasing years of schooling of the head of household by one unit increases the odds for reporting food sufficiency by 12 per cent; likewise increasing the household size by one person increases the likelihood of reporting food shortage by 10 per cent $(\mathrm{OR}=0.901 ; \beta=-0.104)$.

It was furthermore revealed that, households who did not practice farming as major economic activity and those who did not keep livestock as their major economic activity were 69 per cent and 33 per cent respectively, less likely to report that they were food sufficient compared to the counterparts $(\mathrm{OR}=0.31$ and $\mathrm{OR}=0.67$ respectively). From the data presented in Table 7, it is clear that a number of cattle kept, and the number of chicken kept were weak predictors for household food sufficiency as they were both more likely to influence food shortage by less than 10 per cent. On the contrary, the amount of maize and the amount of sorghum harvested were not significant predictors for food sufficiency. Results also showed that there was no likelihood for the annual household cost for food and income to influence food sufficiency in the study area, although they were a significantly important variable in the prediction model. There was 18 per cent more likelihood of a household to report food shortage if they participated in an off-farm activity $(\mathrm{OR}=1.18, \mathrm{p}<0.05)$.

\section{Discussion}

The study shows that household's demographic characteristics such as gender of head of household, marital status, household size and a number of years spent by the head of household in schooling have a significant effect on likelihood of a household to experiences food shortage, contrary to study done in Kitui County in Kenya [28]. In many studies such as and, it has been revealed that a femaleheaded household is more vulnerable to food insecurity [6, 28-31]. Findings in Singida reveal the same results, femaleheaded households have high odds of experiencing food shortage compared to male counterparts. This can be related to the fact that in patrilineal society if the household is headed by a female then it is likely that she is single, separated, divorced or a widow thus less manpower is present at the household level. In the study area, 50 per cent of female-headed household reported to be either single, separated, divorced or a widow, compared to 9 per cent of the male-headed household. This is also complemented by the fact that male-headed household in the study area had an average of four individual aged 15-64 years of age compared to the female counterpart.

Similarly, marital status significantly influenced food availability at the household level, these are also indicated by these studies [32-35]. This may be due to the influence of jointly efforts couples can bring at the family table, thus increasing the chances of having sufficient food. For example, the average annual income estimates are higher by 14 per cent in a coupled household (1,940 US dollar) compared to their counterparts (1,660 US dollar).

In increase in one year of education positively affects the odds of being food sufficient. Formal education has the advantage of allowing an individual to navigate and master different life opportunities by controlling one's surroundings, hence increase the likelihood of being food sufficient. These results substantiate findings from studies done in Malawi and Uganda [34-35].

Locking at household's economic side, off-farm activities have proven to be positively related with food sufficient at household level in the study area compared to when farming and livestock keeping are referred to be major households' economic activities. Similar results were observed mostly in the male-headed household in South Africa, and studies were done in Uganda and Tanzania [31, 35, 36]. Having an alternative source of income at the household level has managed to give a room to household head in providing sufficient food when needed.

Other economic variables, such as annual household's cost on food and household's annual income showed no difference between a household with food shortage versus those with food sufficiency.

\section{Conclusion}

The study set out to explore predictors of food sufficient in Singida Municipality following a persistent report of food shortage despite efforts employed and long society's experience of exposure to semi-arid kind of climate that limit rain-fed agriculture. Employing binary regression analysis on data collected from 6404 households, and taking into account various household socio-economic characteristics, it has been 
observed that; gender of head of household, marital status, household size and number of years spent by head of household in schooling have a significant effect on the likelihood of a household to experiences food shortage.

Furthermore, households involved in off-farming activities had food sufficiency compared to their counterparts who were involved in farming and livestock keeping as major households' economic activities. On the other hand, age of head of household, the amount of staple food harvested, and farm size had no significant effect in determining household food sufficiency.

Actions should focus on; extending extension service toward creating awareness on improved farming method with reduction of dependence on rain-fed agriculture, since education has shown to have positive effect and community at large agreed that the problem of food shortage is much associated with the bad weather condition.

\section{Acknowledgements}

We would like to appreciate the work that was done with the Institute of Rural Development Planning team (2015/16) with their respective students in carrying out well the activity of data collection and data handling. Special thanks go to Stephen Rugaimukamu with his ICT team for figures used in the document.

\section{Competing Interest}

The authors declare that they have no competing interests.

\section{References}

[1] E. Messer and L. F. DeRose, Who's hungry? And how do we know? Food shortage, poverty, and deprivation. New York: United Nations University Press, 1998.

[2] FAO, "The special challenge for sub-Saharan Africa," HighLevel Expert Forum How to Feed World 2050, p. 4, 2009.

[3] NEPAD, "African Agriculture, Transformation and outlook," Johannesburg, 2013.

[4] O. Badiane, S. Benin, and T. Makombe, "Strengthening the Continental Agricultural Agenda and Accountability Framework The Road from Maputo to Malabo," in Africa Agriculture Status Report 2016: Progress Towards Agriculture Transformation in Sub-Saharan Africa, 2016, pp. 26-46.

[5] FAO, The State of Food Security and Nutrition in the World 2017. Building resilience for peace and food security. Rome, 2017.

[6] Abdullah, D. Zhou, T. Shah, S. Ali, W. Ahmad, I. U. Din, and A. Ilyas, "Factors affecting household food security in rural northern hinterland of Pakistan," J. Saudi Soc. Agric. Sci., 2018.

[7] B. Guo, "Household assets and food security: Evidence from the survey of program dynamics," J. Fam. Econ. Issues, vol. 32 , no. 1 , pp. 98-110, 2011.
[8] M. E. Banwat, L. A. Lar, L. B. Dakum, C. S. Igoh, J. C. Daboer, and C. Ogbonna, "Factors Affectinghousehold Food Security in a Rural community in Central Nigeria," Int. J. Community Res., vol. 1, no. 1, pp. 23-29, 2012.

[9] S. Zakari, L. Ying, and B. Song, "Factors Influencing Household Food Security in West Africa: The Case of Southern Niger," Sustainability, vol. 6, no. 3, pp. 1191-1202, 2014.

[10] A. Petralias, E. Papadimitriou, E. Riza, M. R. Karagas, A. B. A. Zagouras, and A. Linos, "The impact of a school food aid program on household food insecurity," Eur. J. Public Health, vol. 26 , no. 2 , pp. 290-296, 2016.

[11] J. de Graaff, A. Kessler, and J. W. Nibbering, "Agriculture and food security in selected countries in Sub-Saharan Africa: Diversity in trends and opportunities," Food Secur., vol. 3, no. 2, pp. 195-213, 2011.

[12] J. Wichern, M. T. van Wijk, K. Descheemaeker, R. Frelat, P. J. A. van Asten, and K. E. Giller, "Food availability and livelihood strategies among rural households across Uganda," Food Secur., pp. 1-19, 2017.

[13] E. Wollenberg, S. J. Vermeulen, E. Girvetz, A. M. Loboguerrero, and J. Ramirez-Villegas, "Reducing risks to food security from climate change," Glob. Food Sec., vol. 11, pp. 34-43, 2016.

[14] M. Y. Mkonda and X. He, "Yields of the major food crops: Implications to food security and policy in Tanzania's semiarid agro-ecological zone," Sustain., vol. 9, no. 8, 2017.

[15] T. S. Jayne and D. Ameyaw, "Africa's Emerging Agricultural Transformation: Evidence, Opportunities and Challenges," in Africa Agriculture Status Report 2016: Progress Towards Agriculture Transformation in Sub-Saharan Africa, 2016, pp. 2-23.

[16] NBS, "National Panel Survey Wave 4, 2014-2015," Dar es Salaam, 2017.

[17] NBS, "Household Budget Survey, 2011/12," Dar es Salaam, 2014.

[18] Twaweza, "Hunger pangs: Food (in)security in Tanzania," Dar es Salaam, 2017.

[19] G. F. Kinyashi, F. G. H. Hawassi, and U. W. Mmari, “Analysis of Household Food Security in Dodoma Municipality: Planned and Unplanned Settlements Comparison," Glob. Forum Food Secur. Nutr., 2010.

[20] J. E. Ntwenya, J. Kinabo, J. Msuya, P. Mamiro, and Z. S. Majili, "Dietary Patterns and Household Food Insecurity in Rural Populations of Kilosa District, Tanzania," 2015.

[21] I. Maltsoglou and D. Dawe, "Household level food security and vulnerability," in Bioenergy and food security: The BEFS Analysis for Tanzania, I. Maltsoglou and Y. Khwaja, Eds. Rome: FAO, 2010, pp. 197-222.

[22] J. Ntwenya, J. Kinabo, J. Msuya, P. Mamiro, D. Mamiro, and L Katalambula, "Household food insecurity and associated factors in rural communities: A case of Kilosa District, Tanzania," African J. Agric. Res., vol. 10, no. 52, pp. 4783-4794, 2015.

[23] H. A. Mbwana, J. Kinabo, C. Lambert, and H. K. Biesalski, "Factors influencing stunting among children in rural Tanzania: an agro-climatic zone perspective," Food Secur., vol. 9, no. 6, pp. 1157-1171, Dec. 2017. 
[24] R. Herrmann, E. Nkonya, and A. Faße, "Food value chain linkages and household food security in Tanzania," Food Secur., Apr. 2018.

[25] L. Kissoly, A. Faße, and U. Grote, "The integration of smallholders in agricultural value chain activities and food security: evidence from rural Tanzania," Food Secur., vol. 9, no. 6, pp. 1219-1235, Dec. 2017.

[26] I. Duda, A. Fasse, and U. Grote, "Drivers of rural-urban migration and impact on food security in rural Tanzania," Food Secur., Apr. 2018.

[27] G. Pierre, K. Pauw, and E. Magrini, "The effect of the National Food Reserve Agency on maize market prices in Tanzania," Rev Dev Econ., vol. 22, pp. 540-557, 2018.

[28] M. M. Milelu, D. M. D. Kigaru, and E. N. Kuria, "Demographic and socio-economic determinants of availability and access dimensions of household food security in Kitui...," Int. J. Food Sci. Nutr., vol. 2, no. September, pp. 3-12, 2017.

[29] W. M. Ashagidigbi, O. A. Afolabi, and I. B. Adeoye, "Food insecurity status among female headed households in Nigeria," Sci. Pap. Ser. Manag. Econ. Eng. Agric. Rural Dev., vol. 17 , no. 3, pp. 69-74, 2017.

[30] B. Tibesigwa and M. Visser, "Assessing Gender Inequality in Food Security among Small-holder Farm Households in urban and rural South Africa," World Dev., vol. 88, pp. 33-49, 2016.

[31] B. Tibesigwa and M. Visser, "Assessing Gender Inequality in Food Security among Small-holder Farm Households in urban and rural South Africa," World Dev., vol. 88, pp. 33-49, 2016.
[32] T. Sekhampu, "Determination Of The Factors Affecting The Food Security Status Of Households In Bophelong, South Africa," Int. Bus. Econ. Res. J., vol. 12, no. 5, p. 543, 2013.

[33] A. Tadesse Tantu, T. Demissie Gamebo, B. Kuma Sheno, and M. Yohannis Kabalo, "Household food insecurity and associated factors among households in Wolaita Sodo town, 2015," Agric. Food Secur., vol. 6, no. 1, pp. 1-8, 2017.

[34] N. Mango, C. Makate, L. Mapemba, and M. Sopo, "The role of crop diversification in improving household food security in central Malawi," Agric. Food Secur., vol. 7, no. 1, pp. 1-10, 2018.

[35] N. Turyahabwe, W. Kakuru, M. Tweheyo, and D. M. Tumusiime, "Contribution of wetland resources to household food security in Uganda," Agric. Food Secur., vol. 2, no. 1, pp. $1-12,2013$.

[36] S. Silvestri, D. Sabine, K. Patti, F. Wiebke, R. Maren, M. Ianetta, Q. F. Carlos, H. Mario, N. Anthony, N. Nicolas, M. Joash, C. Lieven, and R. M. Cristina, "Households and food security : lessons from food secure households in East Africa," Agric. Food Secur., no. 2015, 2016.

[37] S. Silvestri, D. Sabine, K. Patti, F. Wiebke, R. Maren, M. Ianetta, Q. F. Carlos, H. Mario, N. Anthony, N. Nicolas, M. Joash, C. Lieven, and M. C. Rufino, "Households and food security: Lessons from food secure households in East Africa," Agric. Food Secur., vol. 4, no. 1, 2015.

[38] K. Patel, H. Gartaula, D. Johnson, and M. Karthikeyan, "The interplay between household food security and wellbeing among small-scale farmers in the context of rapid agrarian change in India," Agric. Food Secur., vol. 4, no. 1, pp. 1-16, 2015. 